\title{
Patogenesis Human Papillomavirus (HPV) pada Kanker Serviks
}

\author{
Paulina Rosa Evriarti ${ }^{1}$, Andi Yasmon ${ }^{2 *}$ \\ ${ }^{1}$ Program Magister Ilmu Biomedik, Fakultas Kedokteran Universitas Indonesia \\ ${ }^{2}$ Departemen Mikrobiologi, Fakultas Kedokteran Universitas Indonesia \\ *E-mail: andi.yasmon@ui.ac.id
}

\begin{abstract}
Cervical cancer is the most common cancer among women in the world. The main cause of the development of cervical cancer is due to persistent infection of a high-risk type (HR) - Human Papillomavirus (HPV). The mechanisms of HPV in causing cervical cancer are discussed in this article that collected from current information published in a scientific journal. The main target of HPV infection is the basal layer of cervical epithelia and the virus could reach its target when there is a microabrasion of epithelial cells. The HPV binds to its specific receptor on the host cellular surface and followed by the entering virus into the cytoplasm through the endocytosis process. After successfully entering the cell, the virus will uncoat and begin the replication process by hijacking the transcription and translation system of host cells. E6 and E7 proteins play an important role in the inactivation of tumor suppressor proteins p53 and pRb, causing the cells to uncontrolled divide (immortal). If the immune response failed to interfere with the replication process and eliminates HPVinfected cells, the HPV infection will lead to cervical cancer. In conclusion, the mechanism of HPV causing cervical cancer is complex and involves important proteins of HPV.
\end{abstract}

Keyword: Cervical cancer, Human Papillomavirus (HPV), E6, E7, suppressor protein

\begin{abstract}
Abstrak
Kanker serviks merupakan kanker paling banyak kedua yang diderita oleh perempuan di dunia. Penyebab utama dari perkembangan kanker serviks yakni adanya infeksi yang persisten tipe high risk (HR) - Human Papillomavirus (HPV). Artikel ini disusun untuk mengetahui mekanisme HPV dalam menimbulkan kanker serviks. Uraian dan tulisan mengenai isi artikel ini diperoleh dengan melakukan beberapa studi literatur yang terkait dengan HPV dalam menyebabkan kanker serviks. HPV dalam perannya menimbulkan kanker serviks diawali dengan masuknya HPV ke dalam lapisan sel epitel pejamu karena adanya mikroabrasi atau luka kecil. Bila berhasil melakukan pelekatan pada sel epitel serviks melalui reseptornya, virus akan diendositosis dan masuk ke dalam sel. Setelah berhasil masuk sel, virus akan mengalami uncoating, kemudian virus akan memulai proses replikasinya dengan cara mengambil alih sistem transkripsi dan translasi sel pejamu. Protein E6 dan E7 berperan penting dalam hal ini karena adanya kedua protein tersebut menghalangi kerja dari protein supressor tumor p53 dan pRb sehingga sel menjadi imortal dan pembelahan sel menjadi tidak terkendali. Apabila proses ini terakumulasi tanpa berhasil dieliminasi oleh sistem imun, infeksi oleh virus HPV dapat menjadi persisten dan timbul suatu keganasan berupa kanker serviks. Dari paparan tersebut, dapat ditarik kesimpulan bahwa mekanisme HPV dalam menyebabkan kanker serviks merupakan mekanisme yang cukup kompleks dan melibatkan protein-protein penting yang ada dalam genom HPV.
\end{abstract}

Kata Kunci: kanker serviks, Human Papillomavirus (HPV), E6, E7, protein supressor

\section{Pendahuluan}

Kanker Serviks merupakan suatu bentuk keganasan yang terjadi pada leher rahim (serviks) yang disebabkan oleh adanya pertumbuhan yang abnormal dari jaringan epitel serviks akibat adanya infeksi yang persisten human papillomavirus (HPV) tipe high risk (HRHPV) onkogenik. World Health Organization (WHO) melaporkan, kanker serviks merupakan kanker paling banyak kedua yang diderita oleh perempuan di dunia. Di Indonesia kasus kanker serviks mencapai 207 kasus per 100.000 populasi. $^{1,2}$

HPV merupakan virus DNA sirkuler rantai ganda, berukuran kecil, tidak memiliki selubung (envelope) dan masuk dalam keluarga Papillomaviridae. Saat ini, lebih dari 200 jenis HPV yang berbeda telah dikarakterisasi dan sekitar 30 sampai 
40 dapat menginfeksi lapisan epitel saluran anogenital dan area mukosa lainnya pada tubuh manusia. Berdasarkan hubungan mereka dengan kanker serviks dan lesi prekursor, HPV dapat diklasifikasikan menjadi Low Risk-HPV (LR-HPV), potential High Risk-HPV (pHR-HPV), dan High Risk-HPV (HR-HPV). LR-HPV tipe 6 dan 11, dapat menyebabkan kutil kelamin yang umum atau lesi hiperproliferatif jinak dengan kecenderungan tidak berkembang menjadi ganas, sementara infeksi HR-HPV, terutama HPV tipe 16 dan 18, merupakan penyebab utama terjadinya lesi pra-ganas dan ganas pada kanker serviks invasif. ${ }^{3,4}$

Kanker serviks tidak terjadi dalam waktu yang singkat. Butuh waktu sekitar 5-10 tahun dari sejak infeksi pertama sampai berkembang menjadi kanker invasif. Pada beberapa orang, infeksi oleh HPV dapat dieliminasi oleh sistem imun sebelum berkembang menjadi suatu keganasan. Akan tetapi pada individu yang lain, HPV berhasil menghindar dari sistem imun pejamu dan berkembang menjadi kanker. Persistensi HPV pada tiap pejamu berbeda tetapi belum diketahui penyebab yang pasti karena penyebab terjadinya kanker bersifat multifaktorial, namun infeksi HPV merupakan pencetus utama terjadinya kanker serviks. Oleh karena itu, penting untuk mengetahui dan memahami proses terjadinya infeksi HPV sampai berkembang menjadi kanker serviks. ${ }^{5}$ Tujuan dari penulisan review ini adalah untuk mengetahui mekanisme HPV dalam menyebabkan kanker serviks.

\section{Metode}

Review ini merupakan literatur review yang disusun dengan pendekatan telusur kepustakaan dari beberapa literatur seperti buku, artikel, dan jurnal yang berkaitan dengan patogenesis virus HPV dalam menimbulkan kanker pada manusia.

\section{Hasil \\ Klasifikasi HPV}

Klasifikasi HPV dilakukan berdasarkan pada tingkat homogenitas DNA. International Committee on the Taxonomy of Viruses (ICTV) mengelompokkan Papillomavirus ke dalam keluarga Papillomaviridae (awalnya Papillomavirus bersama Poliomavirus masuk dalam family yang sama). Famili Papillomaviridae dibagi lagi menjadi 2 subfamili dengan lebih dari 50 genus. Akan tetapi, hanya 5 genus yang berhubungan dengan infeksi pada manusia yaitu Alphapapilloma virus, Betapapi lloma virus, Gammapapillomavirus, Mupapillomavirus, dan Nupapillomavirus. Namun yang paling sering ditemukan pada pasien adaah genus Alphapapillomavirus (Tabel 1). 
Tabel 1. Klasifikasi Virus HPV

\begin{tabular}{|c|c|c|c|}
\hline Subfamili & Genus & Spesies & Tipe \\
\hline \multirow{15}{*}{$\begin{array}{c}\text { First } \\
\text { Papilloma } \\
\text { virinae }\end{array}$} & \multirow{15}{*}{$\begin{array}{l}\text { Alpha- } \\
\text { papillo } \\
\text { mavirus }\end{array}$} & $\alpha-1$ & HPV 32, HPV 42 \\
\hline & & $\alpha 2$ & HPV 10, HPV 3, HPV 28, HPV 29, HPV 78 \\
\hline & & $\alpha 3$ & HPV 61, HPV 72, HPV 81, HPV 83, HPV 84 \\
\hline & & $\alpha 4$ & HPV 2, HPV 27, HPV 57 \\
\hline & & $\alpha 5$ & HPV 26, HPV 51, HPV 69, HPV 82 \\
\hline & & $\alpha 6$ & HPV 53, HPV 30, HPV 56, HPV 66 \\
\hline & & $\alpha 7$ & $\underline{\text { HPV 18}}$, HPV 39, HPV 45, HPV 59, HPV 68, HPV 70 \\
\hline & & $\alpha 8$ & HPV 7, HPV 40, HPV 43 \\
\hline & & $\alpha 9$ & $\begin{array}{c}\text { HPV 16, HPV 31, HPV } 33, \text { HPV 35, HPV 52, HPV 58, } \\
\text { HPV } 67\end{array}$ \\
\hline & & $\alpha 10$ & HPV 6, HPV 11, HPV 13, HPV 44, HPV 74 \\
\hline & & $\alpha 11$ & HPV 34, HPV 73 \\
\hline & & $\alpha 12$ & RhPV \\
\hline & & $\alpha 13$ & HPV 54 \\
\hline & & $\alpha 14$ & candHPV 90 \\
\hline & & $\alpha 15$ & HPV 71 \\
\hline
\end{tabular}

Keterangan : $\underline{\text { HPV } 16}$ dan $\underline{\text { HPV } 18}$ HR-HPV penyebab kanker serviks

Selain pengelompokan seperti pada tabel 1, HPV juga dapat dikelompokkan berdasarkan tingkat keganasan yang ditimbulkan pada sel pejamu. Ada tiga kelompok HPV berdasarkan tingkat keganasannya yaitu LR-HPV, pHR-HPV, and HR-HPV (Gambar 1).

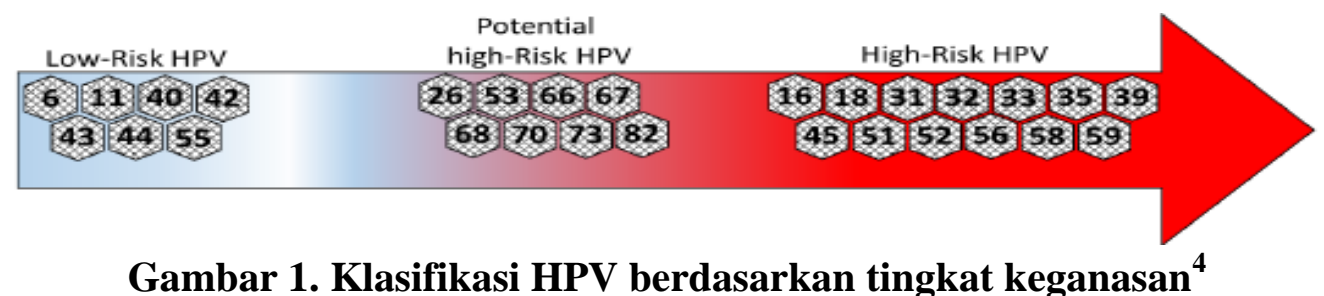

\section{Struktur Genom}

Genom HPV berupa DNA sirkuler rantai ganda berukuran antara $5748 \mathrm{bp}-$ 8607 bp. Genom HPV dibagi dalam 3 region yaitu Upstream Regulatory Region (URR), region protein awal (the early region), dan region akhir (the late region). ${ }^{5,6,7}$ Region URR merupakan $15 \%$ keseluruhan genom HPV dan terdiri atas enhancer element dan promoter. Promoter berperan sebagai origin of replication (ORF) virus yang berfungsi sebagai tempat pengikatan faktor transkripsi seluer. Region ini berada di antara L1 dan E6 ORF (Gambar 2). Enhancer element berperan sebagai faktor penguat proses replikasi dan transkripsi. ${ }^{7,8}$ Region awal terdapat sebanyak $45 \%$ dari keseluruhan genom dan terdiri dari $6 \mathrm{ORF}$, mengkode protein - protein non-struktural (Tabel 2) yang berfungsi untuk mengontrol replikasi DNA dan menginduksi transformasi keganasan dari sel inang. 
Tabel 2. Gen region Awal dan Protein yang Dihasilkan ${ }^{5,8,15}$

\begin{tabular}{|c|c|}
\hline Gen & Protein yang Dihasilkan \\
\hline E1 & $\begin{array}{l}\text { Gen E1 menyandi protein non-struktural E1 yang memiliki ukuran } 73 \\
\text { kDA dan berfungsi dalam replikasi virus HPV. Protein ini bekerja } \\
\text { mengikat sekuen DNA spesifik dan memasang kompleks hexamer } \\
\text { melalui protein E2. Gabungan kompleks ini memiliki aktivitas helikase } \\
\text { yang dibutuhkan untuk oligomerisasi. Protein E1 juga berinteraksi } \\
\text { dengan protein replikasi A (RPA) untuk menjaga stabilitas dari } \\
\text { pembentukan untai tunggal DNA. }\end{array}$ \\
\hline E2 & $\begin{array}{l}\text { Gen E2 menyandi protein E2 yang memiliki ukuran } 40 \mathrm{kDa}-45 \mathrm{kDa} \\
\text { (bervariasi tergantung tipe). Ekspresi dari protein E2 pada sel manusia } \\
\text { menyebabkan transkripsi dari promoter virus. Protein E2 juga berperan } \\
\text { penting dalam produksi virus DNA saat sel pejamu membelah. Lebih } \\
\text { jauh lagi, E2 berinteraksi dengan L2 mengamplifikasi DNA virus. }\end{array}$ \\
\hline E4 & $\begin{array}{l}\text { Gen E4 menyandi protein E4 yang berfungsi dalam proses oligomerisasi, } \\
\text { fosforilasi, dan proteolitik cleavage. Protein E4 juga berperan dalam } \\
\text { mendukung amplifikasi genom virus, regulasi ekspresi gen akhir, dan } \\
\text { mengontrol maturasi atau pendewasaan virus. Protein ini menginisiasi } \\
\text { perubahan koilositotik pada sel epitel. Gen E4 tidak akan diekspresikan } \\
\text { saat genom virus terintegrasi pada genom dari sel pejamu. }\end{array}$ \\
\hline E5 & $\begin{array}{l}\text { Gen E5 menyandi protein berukuran kecil (terdiri dari sekitar } 44 \text { asam } \\
\text { amino) yang tegabung pada membran sitoplasma. Protein ini berfungsi } \\
\text { sebagai penguat dari aktivitas Epidermal Growth Factor Receptor } \\
\text { (EGFR). Protein E5 bersama dengan EGFR dapat mengintervensi jalur } \\
\text { transduksi signal termasuk mitogen-activated protein (MAP) pada jalur } \\
\text { kinase sehingga dapat terhindar dari apoptosis. }\end{array}$ \\
\hline E6 & $\begin{array}{l}\text { Gen E6 menghasilkan oncoprotein yang menghambat kerja dari protein } \\
\text { penghambat tumor yakni protein p53 melalui protein ligase E6. } \\
\text { Akibatnya proses transkripsi dari p53 dan proses apoptosis terhambat. } \\
\text { Protein yang dihasilkan gen E6 juga menginduksi ekspresi dan aktivasi } \\
\text { dari telomerase sehingga menyebabkan sel tidak mati (menjadi tumbuh } \\
\text { abnormal karena tidak adanya proses kematian sel). }\end{array}$ \\
\hline E7 & $\begin{array}{l}\text { Gen E7 menghasilkan oncoprotein yang mengikat protein suppressor } \\
\text { tumor yakni protein retinoblastoma (pRb). Akibatnya pRb kehilangan } \\
\text { kontrol terhadap faktor transkripsi E2F. Selain itu, oncoprotein dari gen } \\
\text { E7 juga mampu mengikat p107 dan p130. Interaksi-interaksi ini } \\
\text { menyebabkan sel tidak mati (immortal) dan meniadakan respon sel } \\
\text { terhadap kerusakan DNA. }\end{array}$ \\
\hline
\end{tabular}

Region terakhir yang disebut dengan Late Region (LR) terdapat sebanyak $40 \%$ dari keseluruhan genom dan terdiri atas dua gen yang mengkode protein struktural dari kapsid. Gen yang pertama yaitu L1, yang dikode menjadi protein yang berukuran 
sekitar 54.000 dalton dan hampir sama ukuran dan susunan asam amino pada tiap jenis virus HPV (highly conserved). Sedangkan gen yang kedua yaitu L2, dikode menjadi protein yang berukuran lebih kecil dan spesifik untuk tiap tipe HPV. ${ }^{8}$ Gen L1 bersifat sangat immunogenik sehingga keberadaan antibody L1 dalam serum pasien digunakan untuk sistem diagnositk. ${ }^{5,19,20}$

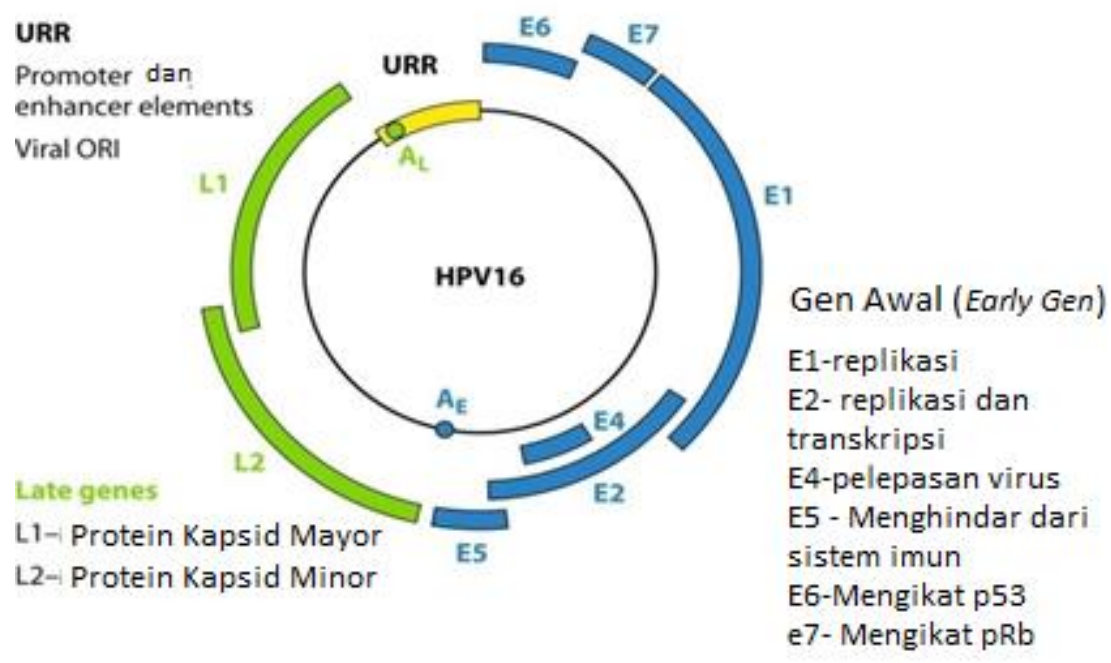

Gambar 2. Struktur Genom HPV $16^{13}$

\section{Morfologi}

HPV merupakan virus double stranded DNA (dsDNA) yang tidak memiliki selubung dengan diameter berkisar $55 \mathrm{~nm}$. Kapsid dari HPV berbentuk ikosahedral dan tersusun atas 72

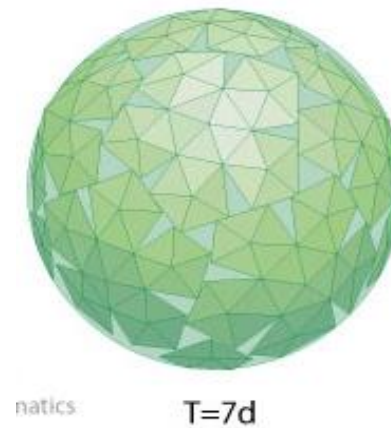

Gambar 3. Human papillomavirus (HPV) ${ }^{6}$

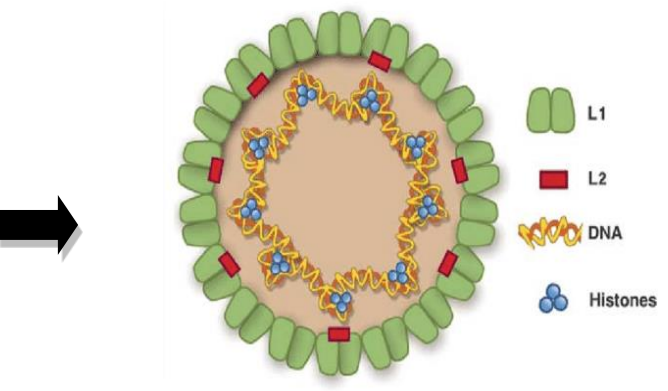

\section{Siklus Hidup}

Siklus hidup HPV tidak jauh berbeda dengan virus dsDNA lainnya. Tahap awal siklus hidup HPV dimulai dengan terpaparnya virus pada sel pejamu. Paparan ini terjadi karena adanya luka atau lesi pada lapisan epitel sel pejamu. Setelah terpapar dengan sel, virus kemudian akan melekat pada sel pejamu melalui reseptor capsomer pentamerik (320 protein L1) dan 12 molekul protein L2. Kapsid ini membungkus satu molekul dsDNA sirkular. Molekul genom HPV berasosiasi dengan molekul histon (Gambar 3). ${ }^{6,19,20,21}$

yang terdapat dipermukaan sel pada lapisan basal epitel. ${ }^{6}$ Umumnya, HPV akan berikatan dengan reseptor primer Syndecan-1 (isotip Heparan Sulfat Proteoglycans (HSPGs) yang dominan ada di permukaan sel epitel) lebih dulu, kemudian HPV akan memodifikasi kapsidnya dan berikatan dengan reseptor sekunder yakni reseptor kelompok 
integrin. ${ }^{7}$ Ikatan yang terbentuk antara virus dengan reseptor yang spesifik dari sel pejamu akan memberikan signal kepada sel pejamu untuk mengendositosis virus. $^{20,21}$ Endositosis virus di awali dengan terbentuknya lekukan pada plasma membran di sekitar tempat melekatnya virus. Lekukan ini kemudian membentuk vesikel yang melingkupi virus. Virus yang telah diendositosis oleh sel, selanjutnya akan mengalami uncoating. Proses uncoating difasilitasi oleh penghilangan ikatan intracapsomer sulfide sehingga kapsid terbuka. Proses ini berlangsung dalam lingkungan sel host. ${ }^{10,20,21}$ Setelah mengalami uncoating DNA virus akan keluar dari vesikel dan mengikat mikrofilamen melalui interaksi region L2 dengan protein motor kompleks dinein untuk membantu transportasi dalam sitolasma dan inti sel. ${ }^{11,21,23}$

Genom HPV akan masuk ke dalam inti sel dan mengaktifkan cascade ekspresi gen virus. Pertama virus akan mengekpresikan protein yang berperan sebagai faktor replikasi yakni protein E1 dan E2. Protein E2 berikatan dengan viral origin of replication virus yang terdapat di DNA virus, ikatan ini memberikan signal pada protein E1 helikase untuk memisahkan untai ganda DNA virus dan membentuk kompleks replikasi. Kompleks replikasi ini akan memberikan signal untuk enzim polymerase dan protein asesori sel pejamu untuk memulai proses replikasi DNA virus. ${ }^{6,7,20,21}$

Seiring degan proses diferensiasi sel epitel, aktivitas promoter akhir (late promoter) akan meningkat. Promoter akhir pada virus HPV akan menginisiasi ekspresi dari dua gen yang mengkode protein struktural (kapsid) virus, yaitu L1 dan L2. Selanjutnya, partikel DNA, bersama dengan protein virus akan dirakit membentuk partikel infeksius pada bagian atas lapisan epitel. Protein L2 berperan membungkus genom virus, sedangkan protein L1 berperan membentuk kapsid ikosahedral pada bagian luar virus. Kemudian, virus HPV akan mengalami eksositosis dan keluar dari sel untuk menginfeksi sel lain yang belum terinfeksi (non-litik). ${ }^{10,23}$

\section{Kanker Serviks}

Kanker Serviks merupakan suatu bentuk keganasan yang terjadi pada leher rahim (serviks) yang disebabkan oleh adanya pertumbuhan yang abnormal dari jaringan epitel serviks. Epitel serviks memiliki tiga zona, zona pertama (ektoserviks) terdiri dari sel epitel pipih berlapis, zona kedua (endoserviks) terdiri dari sel epitel kolumnar selapis, dan zona ketiga adalah zona peralihan dari sel epitel pipih menjadi sel epitel kolumnar (transformation zone). ${ }^{9}$ Jaringan epitel serviks memiliki beberapa lapisan yakni lapisan basal (stratum basal), tengah (stratum spinosum dan stratum granulosum), dan bagian suprabasal (stratum korneum). ${ }^{9}$ Pada tahap awal kanker serviks, ditemukan lesi abnormal sel-sel epitel serviks yang bersifat noninvasif namun dapat berkembang menjadi kanker serviks diberi nama Cervical Intraepitelial Neoplasia (CIN). ${ }^{12}$

Ada beberapa stadium CIN yaitu CIN tahap 1, CIN tahap II, dan CIN tahap III. Pada CIN tahap I, lesi abnormal terjadi pada $1 / 3$ bagian jaringan epitel. Tahap ini memerlukan waktu sekitar 3 tahun dari sejak infeksi pertama terjadi.CIN tahap II lesi abnormal mencapai 2/3 jaringan epitel. CIN tahap III lesi abnormal terjadi pada lebih dari $2 / 3$ jaringan epitel bahkan hampir seluruh jaringan epitel mengalami lesi abnormal (carcinoma in situ). CIN tahap III memerlukan waktu 3-6 tahun. Apabila tidak mendapat pengobatan, infeksi HPV dapat menjadi persisten selama 5-10 tahun dan kemudian dapat berkembang menjadi kanker invasif (Gambar 4). ${ }^{9,13}$

Sel epitel normal (warna sel biru) mengalami mikroabrasi atau luka sehingga partikel virus masuk dan menginfeksi sel basal epitel. Infeksi HPV mulai menyebar ke sel-sel epitel seiring diferensiasi sel epitel (sel epitel warna pink berinti ungu). 
Pada tahap selanjutnya HPV mengintegrasikan genomnya ke sel host (sel warna jingga berinti merah) sehingga terjadi delesi pada gen E2 virus. Delesi gen E2 menyebabkan overekspresi E6 dan E7 yang berujung pada terbentuknya kanker serviks. $^{26}$

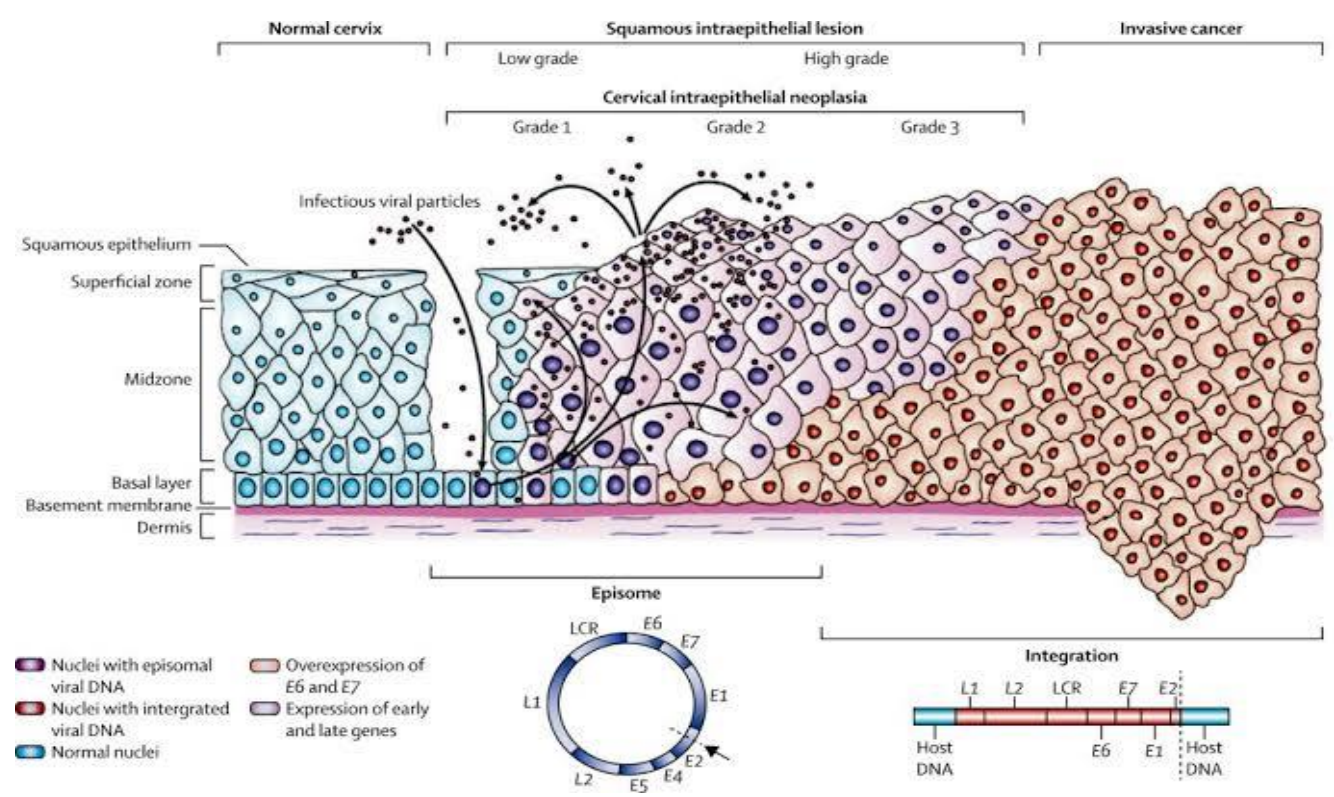

Gambar 4. Perkembangan Kanker Serviks.

\section{Patogenesis Kanker Serviks yang disebabkan Infeksi HPV}

HPV merupakan penyebab utama terjadinya kanker serviks. ${ }^{1}$ HPV dapat menyebabkan infeksi pada sel-sel epitel serviks dikarenakan adanya abrasi atau luka pada jaringan epitel. ${ }^{12}$ Abrasi ini menjadi titik masuk HPV ke dalam sel epitel bagian basal. Sel-sel epitel pada bagian basal merupakan sel-sel epitel yang belum matang dan masih terus berproliferasi. Ekspresi gen HPV semakin lengkap seiring peningkatan maturasi dari sel pejamu. Saat menginfeksi sel basal, HPV kurang reproduktif (replikasi virus terjadi lambat). Replikasi virus terjadi sangat lamban namun konstan. ${ }^{22}$ Pada fase ini, belum muncul perubahan yang abnormal pada sel. Saat sel epitel pejamu matang dan tidak lagi berdiferensiasi, replikasi genom HPV meningkat dan gen E6 dan E7 yang mengkode oncoprotein dan gen L1 dan L2 yang mengkode protein struktural mulai diekspresi. Pada tahap ini mulai terjadi perubahan yang abnormal pada sel (immortal sel) dan terbentuk virion baru dalam jumlah besar yang akan menginfeksi sel epitel lainnya yang masih normal. Akan tetapi, perubahan yang terjadi masih dalam skala yang sangat kecil (CIN tahap I) dan respon imun sebenarnya masih dapat mengeliminasi infeksi pada tahap ini. Namun bila terjadi toleransi, infeksi HPV akan menjadi persisten (Gambar 4). ${ }^{12,25}$

Infeksi HPV yang persisten akan menyebabkan lesi makin meluas dan makin invasif (CIN tahap II dan CIN tahap III). Pada CIN tahap I, genom HPV belum terintegrasi secara sempurna pada sel pejamu bahkan sebagian ada yang tidak terintegrasi dalam genom sel pejamu. Namun, pada CIN tingkat tinggi, DNA HPV sudah terintegrasi sempurna ke dalam genom sel pejamu (Gambar 4). ${ }^{22}$ Integrasi ini menyebabkan terganggunya atau terhapusnya gen pengkode potein E2. Sebagai akibatnya, fungsi protein E2 sebagai regulator transkripsi protein E6 dan E7 terganggu. Hal tersebut menyebabkan peningkatan ekspresi protein E6 dan E7. ${ }^{25}$ Kedua protein ini menghalangi regulasi siklus sel dengan 
cara mengikat dan menginaktivasi dua dan retinoblastoma $(\mathrm{pRb}){ }^{14,22,25}$ protein suppressor tumor yaitu protein p53

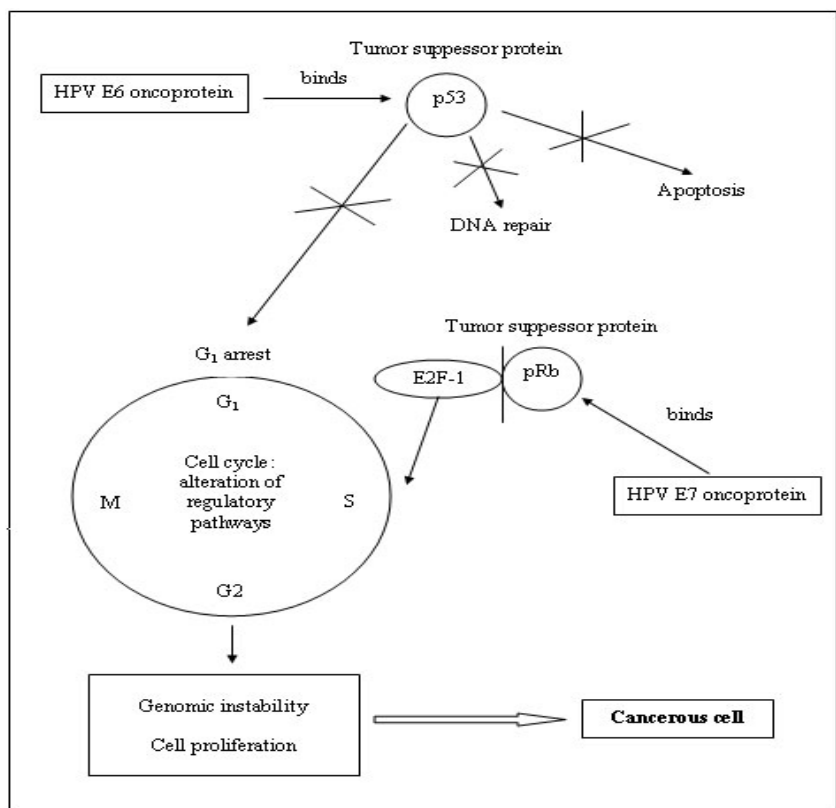

Gambar 5. Peran Protein E6 dan E7 HPV Onkogenik ${ }^{25}$

Protein E6 yang terdiri atas 150 asam amino berikatan dengan protein seluler E6-associated protein (E6-AP) membentuk kompleks enzim Ubiquitin Ligase. Kompleks enzim ini menyebabkan degradasi dari p53. ${ }^{2}$ Degradasi dari p53 menyebabkan aktivitas normal dari p53 seperti memberhentikan siklus sel setelah fase G1, apoptosis, dan perbaikan DNA tidak terjadi (Gambar 5). ${ }^{8}$ Selain itu, protein E6 juga berperan menginduksi protein $c$-myc untuk memicu aktivitas dari enzim telomerase. Akibatnya sel akan menjadi immortal karena telomernya tidak mengalami pemendekan. ${ }^{8,25}$

Protein E7 terdiri atas 100 asam amino membentuk kompleks dengan protein RB yang hipofosforilasi menyebabkan gangguan pada kompleks pRB dan faktor transkripsi seluler E2F-1. ${ }^{8}$ Akibatnya, faktor trankripsi E2F-1 bebas dan terlepas dari untai DNA, sehingga terjadi transkripsi gen yang dibutuhkan untuk masuk kedalam fase $\mathrm{S}$ dalam siklus sel dan menghalangi apoptosis dari sel pejamu
(Gambar 5). Sel pejamu menjadi immortal dan terus membelah tanpa terkontrol. ${ }^{14,25}$

Pada keadaan normal, perubahan pada sel akan memicu respon imun sehingga kelainan pada tahap ini dapat di atasi dan sel-sel abnormal di apoptosis. ${ }^{12}$ Secara alamiah sel yang terinfeksi virus akan melepaskan interferon (IFN) tipe 1 seperti IFN- $\alpha$ dan IFN- $\beta$. Interferon menghambat replikasi virus pada sel pejamu dan mengaktifkan Natural Killer (NK). ${ }^{9,14}$ Akan tetapi HPV menghasilkan protein E6 dan E7 yang dapat menghambat regulasi transkripsi dari faktor regulator interferon 3 untuk mengaktivasi interferon beta sehingga membatalkan respon awal dari sistem imun bawaan terhadap infeksi virus. E7 juga mengikat faktor regulator interferon 1 untuk mencegah aktivasi dari interferon alfa dan beta. ${ }^{1,25}$ Selain itu, protein E6 dan E7 juga menghambat translokasi makrofag ke titik yang terinfeksi virus dengan cara menghambat regulasi Monocyte chemotactic protein-1 (MCP-1), suatu senyawa kemotaksis. ${ }^{9,13}$ 
Normalnya senyawa ini akan dilepaskan oleh sel keratin yang terinfeksi virus sehingga makrofag akan bermigrasi ke sel yang terinfeksi. ${ }^{13}$ Lalu, makrofag akan teraktivasi bila berikatan dengan komponen virus, seperti materi genetik dari virus maupun kapsidnya. ${ }^{12}$ Makrofag yang teraktivasi akan melepaskan sitokin inflamatori, kemokin atau interferon. Senyawa yang dilepaskan makrofag akan memicu TNF- $\alpha$ maupun antibodi untuk membunuh HPV. ${ }^{23}$

Protein E5 dari HPV juga berperan dalam mendukung infeksi persisten HPV. ${ }^{15,25}$ Protein E5 menyebabkan penurunan regulasi reseptor sel $\mathrm{NK} .{ }^{15}$ Penurunan regulasi reseptor mengakibatkan sel NK tidak dapat menempel pada reseptornya sehingga aktivitasnya dalam mengeliminasi sel kanker akan menurun. ${ }^{15}$ Penurunan aktivitas sel NK menyebabkan beberapa sitokin yang dapat memicu respon imun adaptif tidak sekresi. ${ }^{15,25}$

Pada tahap lebih lanjut, respon imun yang terbentuk pada penderita kanker serviks justru makin menguntungkan bagi virus untuk tetap ada dan berkembang. Hal ini dikarenakan, protein-protein yang disintesis oleh virus HPV menghambat regulasi terbentuknya sistem imun adaptif melalui penunrunan aktivitas APC (agen precenting cell). ${ }^{13,25}$ Salah satu APC yang sangat penting dalam respon imun adaptif adalah sel dendritik. Sel dendritik berperan mengubah sel $\mathrm{T}$ naif menjadi sel $\mathrm{T}$ aktif. Kegagalan sel dendritik mempresentasikan antigen HPV pada sel $\mathrm{T}$ naif menyebabkan toleransi imun terhadap HPV. ${ }^{13}$ Sel dendritik yang dapat mempresentasikan antigen pada sel $\mathrm{T}$ adalah sel dendritik yang matur (dewasa). ${ }^{17}$ Sel dendritik yang imatur (tidak memiliki reseptor B7) tidak dapat menstimulasi pengaktifan sel $T$. Meskipun mampu mengaktifkan sel $\mathrm{T}$ melalui sekresi Il-10 dan TGF- $\beta$, yang terbentuk adalah sel $\mathrm{T}$ regulator yang justru merepresi sistem imun. ${ }^{17}$ Proses replikasi dan pelepasan HPV dari sel penjamu juga tidak terjadi secara litik, sehingga tidak memprovokasi pelepasan molekul anti-inflamasi. Infeksi HPV yang asimptomatik merupakan hal yang normal pada wanita yang immunokompeten. Meskipun demikian, rata-rata infeksi oleh HPV dapat dieliminasi dalam kurun waktu satu tahun. ${ }^{1}$ Oleh sebab itu, persisten dan progresi lesi dari sebagian kecil pasien yang terinfeksi HPV tidak diketahui penyebabnya dengan pasti. $^{1,2}$

\section{Kesimpulan}

Mekanisme HPV dalam menyebabkan kanker serviks melibatkan serangkaian protein non-struktural seperti protein E6 dan E7 yang mengakibatkan kegagalan mekanisme apoptosis serta pembelahan sel yang tak terkendali yang berujung pada terbentuknya sel kanker.

\section{Daftar Rujukan}

1. Okechukwu A. Ibeanu. Molecular phatogenesis of cervical cancer. Cancer Biology and Therapy. 2011; 11(3):295 306

2. World Health Organization. World Cancer Report 2008. WHO Press, 2008

3. Serrano B, Brotons M, Bosch FX, Bruni L. Epidemiology and burden of HPV-related disease. Best Pract Res Clin Obstet Gynaecol. 2017;1-13.

4. Holger Stark and Aleksandra Z. HPV vaccination : prevention of cervical cancer in Serbia and in Europe. Acta Facultatis Medicae Naissensis. 2018;35(1): 5-16

5. Fernando Cobo. Human papillomavirus infection. Philadelphia: Woodhead Publishing; 2012

6. Van Doorslaer, et al. ICTV Virus taxonomy profile : Papillomaviridae. Journal of General Virology. 2018; 99 : 989-990

7. Michelle S. Longworth \& Lamonis A Laimins. Pathogenesis of Human Papillomavirus in differenting epithelial. Microbiology and Molecular Biology Reviews J. 2004; 68(2): 362-372

8. A. Alba, et al. The Human papillomavirus (HPV) in human pathology: description, pathogenesis, oncogenic role, epidemiology, and detection techniques. The Open Dermatology Journal. 2009; 3: 90-102

9. Toshiyuki Sasagawa, Hiroaki Takagi, and Satoru Makinoda. Immune responses against human papillomavirus (HPV) 
infection and evasion of host defense in cervical cancer. Journal Infect Chemother. 2012; 18:807-815

10. John Doorbar. The papillomavirus life cycle. Journal of Clinical Virology. 2005; 325:57-515

11. Einstein M, Schiller J, Viscidi R, Strickler $\mathrm{H}$, Coursaget P, Tan T, et al. Clinician's guide to human papillomavirus immunology: knowns and unknowns. Lancet 2009; 9:347-56.

12. Eileen M. Burd. Human papillomavirus and cervical cancer. Clinical Microbiology Reviews. 2003; 6(1) : 1-17

13. Margareth A.S. Epithelial cell response to infecton with human papillomavirus.Clinical Biology Review Journals. 2012; 25(2) : 215-222

14. Daniel T. Gomez and Juana L. Santos. Human papillomavirus infection and cervical cancer. Communicating Current Research and Educational Topics and Trends in Applied Microbiology. 2007 : 680 $-688$

15. Maya Savira. Biologi molekuler Human papillomavirus. JIK. 2017;11(1):1-6

16. Dirjen Yandik Depkes RI, Badan Registrasi Kanker Perhimpunan Dokter Spesialis Patologi Indonesia, Yayasan Kanker Indonesia. Kanker di Indonesia tahun 2018: data histopatologik. Jakarta, 2018.

17. Holger Stark and Aleksandra Z. HPV vaccination : prevention of cervical cancer in Serbia and in Europe. Acta Facultatis Medicae Naissensis. 2018;35(1): 5-16

18. Martinez-Lagunas A, Madrid-Marina V, Gariglio P. Modulation of apoptosis by early human papillomavirus proteins in cervical cancer. Biochim Biophys Acta. 2010; 1805:6-16.

19. Jawetz, Melnick, Adelberg. Medical Microbiology. 24th edition. McGraw-Hill Companies. 2007.

20. Kathleen Park Talaro and Barry Chess. Foundation in microbiology. New York : McGraw-Hill Companies. 2008

21. Alan J. Cann. Principles of molecular virology. USA : Elsevier ; 2012

22. Melissa Kane and Tatyana Golovkina. Common threads in persistent viral infection. Chicago : Journal of Virology. $2010 ; 84(9): 4116-4123$

23. Zheng ZM, Baker CC. Papillomavirus genome structure, expression, and posttransciptional regulation. Frontiers in Bioscience 2006; 11: 2286-302.

24. Dan S, Hong L, Haibo L, Jianrong D. Effect of human papillomavirus infection on the immune system and its role in the course of cervical cancer. Oncology Letters 2015; 10(2): 600-6.

25. Moody CA, Laimins LA. Human papillomavirus oncoproteins: pathways to transformation. Nature reviews cancer. 2010;10;550-560

26. Ciaran BJ Woodmann. The natural history of cervical HPV Infection. Medscape, 2014 